\title{
The Medici's Influence: Revival of Political and Financial Thought in Europe
}

\author{
Sema Yılmaz Genç* - Hassan Syed**
}

\begin{abstract}
The history of the European Renaissance has been written in many versions. The move from medieval to Renaissance period in world history shows clashes between empires and human nature. The contemporary scholars have many variants of history to choose from and form their own views about what actually transpired during the historical period. The most significant role of the Medici family was in the new era of European history that witnessed the art of administration on the Medici Bank in Florence/Italy. This paper portrays the point of view of the influence of IslamicArab scholars as scribes in the re-introduction of Greek-Aristotelian philosophies to Renaissance Europe. This view is being increasingly challenged. The Islamic-Arab scholars such as Averroes and Avicenna were not mere scribes. Better translations of Arabic and Persian historical treasures reveal that the Islamic-Arab scholars during the golden age of Islam were globally accepted literary giants who made profound changes to the ideological shaping of Renaissance Europe.
\end{abstract}

Keywords: Medici Bank, Medieval Europe, Averroes, Avicenna

\section{Medici'nin Etkileri: Avrupa'da Siyasi ve İktisadi Düşüncenin Canlanması}

\section{$\ddot{O}_{z}$}

Avrupa Rönesansı'nın tarihi birçok farklı şekilde yazılmıştır. Dünya tarihinde Orta Çă̆’dan Rönesans dönemine geçiş, imparatorluklar ve insan doğası arasındaki

* Assoc. Prof. Dr., Kocaeli University, Department of Marketing and Advertising, Kocaeli/ TURKEY, semayilmazgenc@kocaeli.edu.tr ORCID: 0000-0002-3138-1622

** Dr., BPP University, Islamic Finance Law, London/UNITED KINGDOM, h.syed2@my.bpp.com ORCID: 0000-0003-2114-2473

DOI: 10.37879/belleten.2021.29

Application date of article: 22.11.2019 - Approval date of article: 16.11.2020

Belleten, Nisan 2021, Cilt: 85/Say1: 302; 29-51 
çatışmaları yansıtmaktadır. Çă̆daş bilim adamlarının, tarihsel dönemde gerçekte neyin meydana geldiğine dair kendi görüşlerini yansitabilecekleri ve oluş-turabilecekleri çeşitli türde tarih yazımı vardır. Medici ailesinin en önemli rolü, onların İtalya’nın Floransa şehrindeki Medici Bankası'nda yönetme sanatına tanıklık eden Avrupa tarihinin, yeni çağında ortaya çıkmıştır. Bu araştırma, Yunan-Aristoteles felsefesinin Rönesans Avrupası'na aktarımında İslam-Arap bilim adamlarının etkisine ilişkin bakış açısını ele almaktadır. Bu görüş, giderek daha fazla sorgulanır ve araştırılır hale gelmektedir. İbn Rüşd ve İbn-i Sina gibi İslam-Arap alimleri salt tarih yazıcıları değillerdi. Arapça ve Farsça yazılmış tarihi hazinelerin daha iyi tercüme edilmesi; İslam'ın altın çağı sırasında İslam-Arap alimlerinin, Rönesans Avrupası'nın ideolojik şekillenmesinde köklü değişiklikler yapan, dünya çapında kabul gören edebi devlet olduklarını ortaya koymaktadır.

Anahtar Kelimeler: Medici Bankası, Orta Çă̆ Avrupası, İbn Rüşd, İbn-i Sina

\section{Introduction}

The Medici family became the bankers of the Christian Pope especially during the times of the two Medici Popes, Pope Leo X and Pope Clement VII. The presentday financial system of international banking is deeply inspired by the practices of the Medici Bank. The Medici family also laid some of the core foundations of the present-day political system in Europe. They realised that any rulership needed the unified approach of combining politics with social reforms of economic prosperity, including scholarship. Thus, this paper touches upon these particular aspects of the Medici family's profound impact on Renaissance Europe.

The Medici family rose to prominence as one of the leading financial families of not only Florence but also Italy. Their rise was a result of the financial turmoil faced by the Bonsignoris of Siena in 1298 AD. The turmoil also led to the shifting of the financial hub of Renaissance Italy from Siena to Florence ${ }^{1}$. The Medici family's immediate influence on Italian politics, the Roman Christian Church², and later French monarchy is a historical story that addresses some of the most significant social, political, and financial events of the times. Especially Lorenzo De' Medici (1449-1492) is one of the most influential rulers in the Medici family. His role as a patron of art and literature left a lasting mark on the artistic and

1 Friedrich Heer, The Medieval World: Europe, 1100-1350, Signet, 1998, p. 98.

2 Della Famiglia De Medici in Firenze Appresso Bartolommeo Sermartelli e Fratelli MDCX, https://archive.org/details/dellafamigliadem00stro/page/n3, p. 5. 
literary heritage of Europe from the Italian Renaissance. The family's indirect influence on the European continent continues to this day.

To this end, the theme of this paper is to understand the link between the role of Averroism in Medieval Europe associated with the University of Padua in the early Italian Renaissance and the subsequent development of Greek Philosophy that shaped the political thought of Europe which continues to this day. This study traces the history of Greek philosophy briefly from $300 \mathrm{AD}$ onwards during the Roman Christian Empire and how the Islamic world helped to shape the later re-importation of Greek Philosophical works of Aristotle and Plato back into Europe. This part of the European history is extremely important to understand how after the Christian Roman Church of the $4^{\text {th }}$ century annihilated any doctrine that opposed the Christian views of the $4^{\text {th }}$ and $5^{\text {th }}$ centuries and the post-Renaissance re-emergence of the Greek Philosophy in Europe. The fact that the crucial role played by the Medici family through their protection and patronage of Pro-Platonian scholars and artists ensured that the ancient Greek Philosophy was nurtured and protected from the powerful Roman Church which deserves a deeper insight. The study also explores the major work undertaken during the Medici ruler Lorenzo the Great's lifetime. The influence of Ibn Rushd or Averroes on Christian scholars who revived the Greek Philosophy in Europe is noteworthy. Hence, this paper challenges the altered existing linear historical narrative that not only precludes the remarkable impact of Islamic Scholars during the Renaissance and Post-Renaissance political thought of Europe but also minimises the role of the Medici family for their patronage of such scholarly work. This study also summarily addresses one of the strong allegations against the Medici family in this regard for colluding with the Roman Church of placing a $10 \%$ or tithe to be given to Church and the Medici Bank as the collector and depositor of the tithe on behalf of the Church. On the other hand, allowance of Church to the Medici Bank to expand its political influence was a shift in the doctrine of usury and this study proposes that this changed forever the landscape of money trade which continues to this day ${ }^{3}$.

3 "The Medici Bank became the official bankers of the Church and together they 'created what had to be one of the cleverest enterprises of all time' wherein the Medici bank collected 10\% of an individual's earnings for the Church (PBS Research Team). This partnership was very rewarding for the Medici. It gave them immense power and massive earnings and also enabled them to be ahead of their other business rivals, all of these in the short time of Pope Fohn XXIII's papacy - 1410-1415" Brugena, Justine Grace N., "The Medici and the Catholic Church" Western History: From Modern Times to Present, (2014) pp. 1-17 


\section{Historical Background}

The Medici Bank was founded in 1397 AD by Giovanni Di Bicci De' Medici (1360-1429) who ruled the bank till 1429 AD. The Medici Banks's last head was Piero Di Lorenzo De' Medici (1472-1503) who saw its demise in $1494 \mathrm{AD}^{4}$. The times during which the Medici Bank flourished and expanded also signifies the role of the Medici's in strengthening their ties with the Papal Leadership in Rome. The significance of their close ties with the Church resulted in securing the Church's investments in the Medici Bank ${ }^{5}$. The Medici Bank's gold-based currency Florin $^{6}$, started by the Medici family in 1253, is considered amongst the first currency coins in Europe. Florin was considered the currency of choice across Europe for inter-trades.

The Medici Bank had branches all over the major regions of Italy by $1430 \mathrm{AD}$ and had expanded its business across Europe to Switzerland and Belgium ${ }^{7}$. The most significant role of the Medici family is in shaping the European political and financial thought through their use of the Medici Bank in Florentine Italy. ${ }^{8}$ The reason for the rapid expansion apart from the political negotiations and strong social network was the Medici's development of an advanced accounting system that sustained their exponential growth ${ }^{9}$. The Medici family also used religious means, such as baptism, to expand and consolidate the trade network ${ }^{10}$.

4 Richard A. Goldthwaite, 'The Medici Bank and the world of Florentine Capitalism", Past \& Present, No. 114, 1987, p. 4.

5 Tim Parks, Medici Money: Banking, Metaphysics, and Art in Fifteenth-Century Florence, WW Norton \& Company, 2005, p. 15.

6 D. Havelock Fisher, "The Medici Account-Books", The American Historical Reviere, Vol. 33/4, 1928, p. 830.

7 Raymond De Roover, "New Perspectives on The History of Accounting", The Accounting Review Vol. 30/3, 1955, p. 410.

8 George Frederick Young, The Medici, Vol. 1, EP Dutton, 1917, p. 13.

9 Parks, Medici Money: Banking, Metaphysics, and Art in Fifteenth-Century Florence, p. 61

10 "AUTHORITY of certain MERCHANTS of RAGUSA to enable others to stand sponsors in their stead at the baptismal font, for the sons or daughters of RAFFAELLO DI FRANCESCO DE' MEDICI and NICCOLO CALCIDONE, so that the spiritual relationship may be contracted; 16 May 1506 (in a bad state of preservation) CONTEMPORARY COPY of the ENTRY of NOMINATION of FRANCESCO DE' MEDICI to be Captain of Cortona; 30 January 1507 INSTRUMENT referring to the levelling of certain LANDS belonging to the NERONI FAMILY; 1507-1508, 3 pp. WILL of DONNA FRANCESCA SALVIATI : 12 August 1510 (very bad condition) 4 Documents, folio." Catalouge of The Medici Archives Consisting of Rare Autograph LettersRecords and Documents 1084-1770 Including One Hundred And Sixty-Six Holograph Letters Of Lorenzo The Magnificent The Property of 
The rise and fall of the Medici Bank in 1494 is beyond the discussion topic of this paper. The main interest lies in the impact that the Medici banking had on the development of Renaissance Europe till today. There are many historical reasons that have been debated for the decline and final collapse of the Medici Bank. The most potent reason emerges in the form of the English Monarchy's large debt owed to the Medici Bank's London branch and the ultimate default by the British Royalty leading to the imposition of severe sanctions on the businesses linked with the Medici Bank ${ }^{11}$.

\section{The Medici Bank and Its Influence on the Roman Ghurch}

The Medici Bank of Florence at its inception is the result of the demise of the city of Siena as the financial and banking centre of Italy. The European banking and finance sector in the pre and post-renaissance period cannot be known entirely without understanding the crucial underlying ideologies underpinning the financial and banking sector through the social doctrines of the Roman Church.

The Roman Church provided the only frame of reference and the guiding principles for the governance of any states at the time. The social obligations of the society were therefore strongly guided by the Roman Church in Europe at the time. The Church also exerted its powers to dictate to the entire Christian population within Europe, which covered whole Europe, regarding how financial transactions had to be done. The link between the Medici family and the Roman Church was not only through financial instruments. In the correspondence between Cosimo de Medici and the Papacy, which is addressed as the Duke of Florence, a diplomatic process which is much intertwined is also significant. In a letter dated July 1529, it is seen that Francesco De' Medici is authorised in the negotiations to be held as the papal representative ${ }^{12}$.

The Marquis Cosimo De' Medici and The Marquis Averardo De' Medici, https://archive.org/ search.php?query $=$ medici\&page $=2$, (1918), p. 24.

11 Raymond De Roover, The Rise and Decline of the Medici Bank: 1397-1494, Vol. 21, Beard Books, 1999, p. 194.

12 "CLEMENT VII. (POPE), BRIEF, signed "BLOSIUS," 1 p. oblong folio, 11 June 1529, accrediting FRANCESCO DE' MEDICI to treat of certain matters with the Viscount Galeazzo (?), when on his way to a mission to M. de Saint Pol, Captain General of the Most Christian King in Italy." Catalouge of The Medici Archives Consisting of Rare Autograph Letters Records and Documents 1084-1770 Including One Hundred And Sixty-Six Holograph Letters of Lorenzo The Magnificent The Property of The Marquis Cosimo De' Medici and The Marquis Averardo De' Medici, p. 25 
The Roman Church exercised the spiritual monopoly that extended to the economic monopoly through its exclusive right to interpret all matters of divine law. The feudal society having harsh social conditions for most people during the time gave the Roman Church exclusivity over the postulation of doctrinal principles ruling all aspects of life. The sale of ecclesiastical offices of the Church during the time of Pope Boniface IX (1389-1404) added so many profits to the papal wealth that it became an accepted part of the spiritual doctrines of the Church ${ }^{13}$. By the time of the appointment of the Medici Pontiff Leo X (1513-1521), son of Lorenzo De' Medici, the papal income from such sales amounted to $1 / 6^{\text {th }}$ of the entire income of the papal wealth ${ }^{14}$. This economic monopoly of the Church extends from the reign of Pope Gregory VII (1073-1085) who systematically changed the status of papal authority to a Monarch and reduced the powers of the princely rulers within the Christian world.

With this brief but elaborate background in mind, it can be better understand the Medici family's efforts to not only win the business of the papal leadership but at the same time leverage their financial position to buy the highest papal rank. Pope Leo X, Pope Clement VII, and Pope Leo XI were all Medici's and they strengthened the financial hold of the Medici Bank by becoming not only the Bankers for the Pope but also for various monarchs within the Christian world. The Medici Bank's Rome branch earned the title of "INostri Che Seguono la Corte di Roma"15 or the Bank that follows the Court of Rome.

\section{The Medici Bank's Introduction of Political Finance}

The most interesting aspect of the Medici Bank is the era in history when it rose to prominence. The unique nature of the Medici Bank in terms of its trade is not so much about money or commodities that it controlled all over Europe; it was the Bank's ability to trade in politics. The Medici Bank became the agent of change that dealt with the politics of the European states by lending money to feudal and

13 Robert B. Ekelund-Robert F. Hébert-Robert D. Tollison, "An Economic Model of The Medieval Church: Usury As A Form of Rent Seeking", fournal of Law, Economics, E Organization, Vol. 5/2, 1989, p. 308.

14 Peter Partner, "Papal Financial Policy in the Renaissance and Counter-Reformation", Past Eீ Present, Vol. 88/1, 1980, p. 22.

15 Francesco Guidi Bruscoli, Papal Banking in Renaissance Rome: Benvenuto Olivieri and Paul III, 15341549, Routledge, 2017, p. 69. 
royalty while they waged wars. The close relationship of the Medici Bank with the Roman Church gave it the added advantage to also offer the Pope's approval. At the same time, it engaged in the negotiations with various royal families across the Christendom to engage in financial advantages through the on-going conflicts. These brilliant manoeuvrings by the Medici may not make much sense in the contemporary era; it made perfect sense in a time when the global superpower was the Roman Church, and it was the Pontiff who decided the fate of royalties all across the Christendom. The letter written by Lorenzo de Medici on May 11, 1489, suggests that the European monarchs, including the Spanish throne, were arbitrators in the political environment, arguing the pope's displeasure for the current economic situation in the conflict ${ }^{16}$.

In case of political influence towards the Roman Church, a very important source of the Medici family's political power, the ability of the Medici rulers to comprehend the power-struggle that shook every realm within Europe and their strategy to survive and emerge as a prominent family that almost 'shared' the monopoly of the Roman Church was unique in that era.

The Roman Church in the $14^{\text {th }}$ and $15^{\text {th }}$ Centuries shifted its position towards the strict edifices of the doctrine that prohibited usury and its social impact. The Usury was a topic of severe contention during the Renaissance period. Usury's doctrinal value for the present-day Catholic Church remains inert today, and the Medici Bank played a significant if not vital role in changing the doctrine on usury.

When taking a closer look at the period of Roman Church starting to shift its strict views about usury towards a more tolerable and exception-oriented view, it can be seen that the content of time needs to be remembered when the average person in the feudal system of Renaissance Europe did not have access to much money; instead, barter of subsistence goods was the norm ${ }^{17}$. The doctrinal corpus of the Roman Church's teachings in its Magisterium ${ }^{18}$ or through the Ecumenical

16 “MEDICI (LORENZO DE' [THE MAGNIFICENT]), A.L.S., 31 pp. folio, Florence, 11 May 1489, to PIETKO ALAMANNI." Catalouge of The Medici Archives Consisting of Rare Autograph Letters Records and Documents 1084-1770 Including One Hundred And Sixty-Six Holograph Letters of Lorenzo The Magnificent The Property of The Marquis Cosimo De' Medici and The Marquis Averardo De' Medici, p. 35.

17 Erik Reinert-A. Daastol, The Other Canon: The History of Renaissance Economics, Cheltenham, Edward Elgar 2004, p. 26.

18 Charles E. Curran-Richard A. McCormick, The Magisterium and Morality, 1982, p. 30. 
Councils $^{19}$ on the topic of usury proclaims a very strict dictum. The entrance of the enigmatic Medici's Cosimo and Lorenzo De' Medici influencing the Roman Church through the Medici Bank and the Church's strict doctrines of theology became a matter of financial politics. The usury topic did not become settled law at the time of the Medici's as witness the statement of the $17^{\text {th }}$ century Pontiff Benedict XIV who declared, the sin of usury in the matters of loaning money for the sole purposes of mark-up alone without any other activity ${ }^{20}$.

The history of the Medici Bank is quite clear that their loans to the royalty, traders, nobles, etc. were purely based on interest or usury. How did the Medici Bank keep the sin of usury away from its massive wealth accumulation by charging interests not only on its wealth but also on the wealth that it held for the Roman Church itself?

The Medici who were patrons of scholars such as Count Pico ${ }^{21}$ were aware of the rising awareness during the Renaissance of Aristotelian philosophies of Physical and Metaphysical nature's distinctions between human consciousness. The Medici promoted the ancient Greek philosophies through their patronage of scholars at the only University at the time, Padua. Averroism ${ }^{22}$ was taking roots in Europe. It may be a leap of assumption; however, this study proposes that the Medici Bank kept the contentious matter of usury at bay by encouraging ${ }^{23}$ the theological framework through the distinction between manifest and hidden usury. The Papal Bulls $^{24}$ allowed this extension and the Exchangers Guild ${ }^{25}$ of Florence declared the

19 Canon XVII of the First Ecumenical Council of Nicea in AD 325: "Since many clergyman have been induced by greed and avarice to forget the sacred text, "who does not put out his money at interest", and to charge one per cent a month on loans, this holy and great synod judges that if any are found after this decision to receive interest by contract or to transact the business in any other way or to charge a rate of fifty per cent or in general to devise any other contrivance for the sake of dishonourable gain, they shall be deposed from the clergy and their names struck from the roll." Leo Donald Davis, The First Seven Ecumenical Councils (325-787): Their History and Theology, Vol. 21, Liturgical Press, 1990, p. 60.

20 "Vix pervenit ex cathedra encyclical" was promulgated by Pope Benedict XIV on November 1, 1745 to condemn usury. Bryan S. Turner, Max Weber-Critical Responses, Routledge 1999, p. 49.

21 Giovanni Pico Della Mirandola (1463-1494).

22 It will be explained in the later part of this paper.

23 De Roover, The Rise and Decline of the Medici Bank: 1397-1494, p. 12.

24 P. J. Marshall, Proceedings of the British Academy Volume 125, 2003 Lectures, Vol. 125, Proceedings of the British Academy, 2005, p. 26.

25 Jack Cashill, Popes and Bankers: A Cultural History of Credit and Debt, from Aristotle to AIG, Thomas Nelson, 2010, p. 41. 
Medici Bank. Similarly, working on the principles of hidden usury and street money lenders who are mostly Gentile Jews were labelled as indulging in manifest usury punishable by a financial fine.

This ingenious yet theoretical extension of the doctrine of Usury introduced by the Church $^{26}$ allowed the Medici Bank to flourish and expand its political influence. Scholars have sometimes ignored this subtle but fundamental shift in the Church doctrine. While religion has long since lost its control in the European policymaking domain, yet the change in the doctrine of usury enabled by the Medici Bank resonates even today. This study will go no further than this discussion on the Medici Bank's influence that included the re-introduction of the concept of Dry Exchange $^{27}$ through the efforts of the founder of the Medici Bank Cosimo De Medici to circumvent the Church's strict doctrine of usury. A Dry Exchange was a medieval concept of lending money without any transfer of goods with guaranteed interest to the lender. Dry Exchange was declared usury by the Roman Church and forbidden by Canon Law. The law was suspended at the behest of the Medici Bank.

The Medici Bank, through their effective control on the Papal Office, ensured legalising the charging of interest on activities of the royalties and nobles through the funding of their conquests at a fixed-rate. In return for the Church's assistance in changing the 9-centuries old doctrine on Usury, the Medici Bank invested in building magnificent Cathedrals and adorning of Papal Palaces including commissioning of artworks in the chosen cathedrals. The centre of Renaissance art and architecture shifted from Florence to Rome at the end of the Medici Bank, which also marks the decline of the Medici in Florence ${ }^{28}$.

The Medici family influenced European political thought in more than one way. The Medici Bank and its introduction of the 'Financial Politics' to the European thought can be seen today in the shape of Central Bank regimes all through the world. The world economies seek their directions from these central economic institutions, and in return, these institutions direct the political fate of the world as a whole. The Medici Bank introduced this form of financial politics in a time when European politics was feudal in nature, and there were no other central institutions such as the ones as in today except the Roman Christian Church.

26 Jacques Le Goff, The Usurer and Purgatory, in The Dawn of Modern Banking, 1979.

27 Paul Strathern, The Medici: Godfathers of the Renaissance, Random House, 2018, p. 55.

28 T. Parks, Medici Money: Banking, Metaphysics, and Art in Fifteenth-Century Florence, WW Norton \& Company, 2005. 


\section{Machiavelli's Prince and Lorenzo De’ Medici}

Niccolò Di Bernardo Dei Machiavelli (1469-1512) was a native of Florence and his most famous political work II Principe' or The Prince ${ }^{29}$ appeared sometime around 1513 and was not written in scholarly Latin but the vernacular Florentine Italian $^{30}$. The book was published through the papal permission granted by the Medici Pope Clement VII. Machiavelli dedicated The Prince to Lorenzo di Piero de' Medici (1492-1519). This enigmatic Medici became the ruler Duke of Florence at the age of 24 through the papal appointment by his uncle Pope Leo X. He ruled Florence from 1516 to 1519. It is astonishing that while Machiavelli's true rise in public office was not during the Medici rule, he still dedicated his most famous work to a Medici prince ${ }^{31}$.

Machiavelli's name resonates in the political canon as the re-introduction chapter in Europe. The standard historical narrative states that the ancient Greek philosophies of Plato and Aristotle remained absent from the world and reappeared in Europe after a gap of more than 800 years. In this part, to shed some light on the most famous political philosopher in the renascent period of European political thought, Machiavelli's political thought points to the influences of Averroes's work on Plato and Aristotle translated into Latin from Arabic. Machiavelli's main theme for the Prince has been urged for centuries since its first publication for a myriad of political philosophies that range from challenging the pre-renaissance Roman Church's political thought of the Church being the absolute authority in all matters temporal and spiritual to the later periods of republican ideals that even influenced North American political icons such as Adam Smith ${ }^{32}$.

The fact remains that Machiavelli chose a Medici prince as the 'Prince' in his seminal work. The answer to this question can perhaps be that the Medici of Florence were not just rulers confined to their influence in the Italian peninsula rather their fame through the Medici Bank and their influence on the only socalled Super Power of the time, the Roman Church, which made them a symbol of unique political power at the time. That was the power and influence of the

29 Niccolò Machiavelli, The Prince, (Translation by George Bull), Penguin, London 1961.

30 Allan H. Gilbert, Machiavelli's Prince and its Forerunners, 1938, p. 72.

31 Hans Baron, "Machiavelli: the republican citizen and the author of' The Prince", The English Historical Review, Vol. 76/299, 1961, p. 220.

32 Paul A. Rahe, Machiavelli's Liberal Republican Legacy, Cambridge University Press, 2005, p. 167.

Belleten, Nisan 2021, Cilt: 85/Say1: 302; 29-51 
Medici's financial politics that Machiavelli conveys very carefully the ideals of the free republic in which he challenges the power of the Church. It was this challenge that Machiavelli's work represented to the Church through the references to the prince that made Pope Paul IV place Machiavelli's work on the Index librorum prohibitorum or the list of works prohibited by the Roman Church as heretical and a threat to the Christian faith. Machiavelli's dedication to the Medici prince also signifies the advice that he offered to the Medici prince in securing his rule. It is Machiavelli's acknowledgement of the Medici economic and social connections that were the strength of the Medici Bank ${ }^{33}$.

\section{The Medici's Influence on Revival of Political Thought}

The Medici family, through their financial politics based on their Medici Bank, resulted in their most profound influence on the political thought that started during the Italian Renaissance and continues till today. The scholars and artists who were protected and patronised by the Medici produced some of the most outstanding and brilliant works in world history. Even though the standard historical narrative of the political canon from the Medici times shows the reclaiming of ancient Greek philosophy through its links to Machiavelli's work, the re-introduction of the ancient Greek philosophies did occur at the time of the Medici rule in Florence. However, it was not Machiavelli who marks the reintroduction of the ancient Greek philosophies of Plato and Aristotle to Europe. This study asserts that it was the Arabic works of Averroes on the ancient Greek philosophies that allowed the re-introduction of the ancient Greek philosophies to Renaissance Europe. The scholarly literature's aiming to diminish the role of Islamic-Arab scholars in the rejuvenation of Greek philosophies in Renaissance Europe is often described as the history's Great-gap ${ }^{34}$. The Medici made a vital contribution through their patronage and protection of Averroism.

While there are competing arguments for and against the approach to study ancient political theory through the study of the political canon, it remains undisputed ${ }^{35}$

33 Mary G. Dietz, "Trapping the Prince: Machiavelli and the Politics of Deception", American Political Science Reviere, Vol. 80/3, 1986.

34 S. M. Ghazanfar, "History of Economic Thought: The Schumpeterian "Great Gap", the "lost" Araba-Islamic Legacy and the Literature Gap", Medieval Islamic Economic Thought, Routledge, 2004, p. 88.

35 Terence Ball, Reappraising Political Theory: Revisionist Studies in The History of Political Thought, Vol. 2, Oxford University Press, 1995, p. 68. 
that the study of political canon is the best way to define and comprehend the human evolution of political thought. The other criticism against the political canon is that it does not consider non-European political thought based on ancient Greek texts. This argument is based on the fact that the later translators of Latin and Greek canons chose to ignore the fact ${ }^{36}$ that the basis of their work was the Arabic translations of the ancient Greek text themselves.

It was simply a matter of creating a historical narrative that would gloss over the influence of Eastern scholars on political canons themselves. In short, if the political canons are considered to be uniquely European, then it remains to be seen what the Eastern scholars have to say about the political thought based on ancient Greek philosophies of Plato and Aristotle. This study does not go any further than the two Islamic scholars Avicenna and Averroes. Both scholars remain solidly pivotal in the re-introduction of Platonian and Aristotelian Greek philosophies during the European Renaissance ${ }^{37}$. The fallacy of the current historical narrative of the political canons being Western or European would fall apart also if one is to consider Averroism as a core philosophical concept amongst the leading scholars of political thought in the late $13^{\text {th }}$ century Europe. However, if the political canons that are considered to be purely European accept the profound influence by the Islamic scholars such as Averroes, then it is a different story altogether. This defence of the proposition is beyond the scope of this paper. A most brilliant and comprehensive study on the topic has been conducted by Bullock ${ }^{38}$.

Bullock explained that it would not be fair to call it just 'western political theory' as Plato and his acclaimed pupil Aristotle lived at different times then what is perceived as East-West today. The notion of giving the tinge of East-West distinct divide pertaining to the history of political thought flags a tension between 'civilisations' as a contentious topic ${ }^{39}$. This narrow narrative of linear history has been challenged ${ }^{40}$. Not only was the political thought prevalent in the so-called

36 Marshall G. S. Hodgson, The Venture of Islam, Volume1. Conscience and History in a World Civilization. The Classical Age of Islam, The University of Chicago Press, Chicago and London, 2009, p. 103.

37 Seyyed Hossein Nasr - Oliver Leaman, History of Islamic Philosophy, Routledge 2013, p. 68.

38 Katherinig H. Bullock, "Re-Telling the History of Political Thought", American fournal of Islamic Social Sciences, Vol. 19/1, 2002, p. 29.

39 Jones Irwin, Averroes' Reason: A medieval Tale of Christianity and Islam, 2002.

40 Samuel Fleischacker, The Ethics of Culture, Cornell University Press, 1994.

Belleten, Nisan 2021, Cilt: 85/Say1: 302; 29-51 
East that comprised Arabia, China, and India at the time of Plato and Aristotle, but also there were converging philosophies between the two ${ }^{41}$.

This narrow view elucidated above also conveniently interchanges ancient Greek philosophy with the history of western political thought by creating an unbreakable link in the political thought from the times of Plato and Aristotle to the present time. This oversimplified Eurocentric historical account of claiming Plato and Aristotle's political philosophies as the foundation of European Civilization is akin to a parallel reality in a parallel universe distinct from ours ${ }^{42}$.

It would be not easy to defend the historic position offered by the linear narrative of the history of political thought explained above if one is to consider the massive body of scholarly work that exists on Plato and Aristotle in the Arabic text of the medieval and classic areas ${ }^{43}$. The political canons would not be able to sustain the claim of exclusivity to Plato and Aristotle in the light of even the single works of Averroes. The Christian Roman Empire destroyed the academies of Platonic and Aristotelian philosophy by $3^{\text {rd }}$ century $\mathrm{AD}$ with the exception of Athens and Alexandria ${ }^{44}$. By the middle of $6^{\text {th }}$ century AD, the Christian version of the Aristotelian academy survived in Alexandria alone. While the libraries of Athens and Alexandria were destroyed by the Roman Church, Baghdad and Damascus emerged as the centre for scholarship in all domains of knowledge that included the flocking of fleeing Greek scholars of Plato and Aristotle, who had fled the wrath of the Roman Church. It was between the period of $6^{\text {th }}$ century AD and $9^{\text {th }}$ century $\mathrm{AD}$ that all the ancient Greek texts, including Plato and Aristotle, were successfully translated into Arabic ${ }^{45}$. The Arabic language scholarship on political thought based on philosophy, including Plato and Aristotle, created a comprehensive corpus philosophic that ultimately found its way back in Europe during the Italian Renaissance.

41 Marshall G. S. Hodgson, Rethinking World History: Essays on Europe, Islam and World History, Cambridge University Press, 1993, p. 110.

42 Siep Stuurman, "The Canon of The History of Political Thought: Its Critique and A Proposed Alternative", History and Theory, Vol. 39/2, 2000, p. 148.

43 Rosamond E. Mack, (Book Review), "Bazaar to Piazza, Islamic Trade and Italian art, 13001600", Middle East fournal, Vol. 56/4, 2002, p. 722.

44 F. E. Peters (Book Review), Aron Rodrigue, "Jews and Muslims: Images of Sephardi and Eastern Jewries in Modern Times", International Journal of Middle East Studies, Vol. 37/2, 2005, p. 295.

45 Yegane Shayegan, "The Transmission of Greek Philosophy to the Islamic World", History of Islamic Philosophy, Vol. 1, (1996), p. 91. 
This study suggests that a pragmatic and historically factual analysis of the political thought progression from the times of Plato and Aristotle to the European Renaissance must not subject itself to the biases of the East-West divide. Rather, the scholarship that assisted in allowing us to benefit from the ancient Greek thought must be studied in its entirety. It is for this purpose that this study intends to shed some light on the role of the scholars during the so-called dark ages of European history till its revival especially during the Italian Renaissance led by the Florentine's Medici ruler Lorenzo De’ Medici (1449-1492).

\section{The Influences of Ibn Rushd's Aristotle and Plato Studies on the Italian Renaissance}

The earliest known Latin works of Plato and Aristotle are the $12^{\text {th }}$ century Arabic to Latin translations completed in Toledo by Dominic Gundisalvi ${ }^{46}$. Dag Nikolaus Hasse $^{47}$ in his seminal paper on Arabic-Hebrew-Latin translation sheds important light on the understanding of the social settings for the purposes of a meaningful review of the Arabic text translations in the medieval and Renaissance Europe. He proposes that the first wave of Renaissance translations from Arabic to Hebrew and Latin were focused on Avicenna (Ibn Sina) and Averroes (Ibn Rushd). The Padua University was the focal point for the first wave of Arabic to Hebrew and Latin translations of Avicenna and Averroes ${ }^{48}$.

Ibn Rushd or his Latinate version of his Arab name Averroes (1126-1198 AD) was an Andalusian Muslim Scholar par excellence. He was an Islamic scholar who works in Medicine, Physics, Astrophysics, logic, philosophy, and law beyond dispute. What is not readily and properly acknowledged by some historical writers is the deep influence of Ibn Rushd's work on the political thought both in the classical as well as contemporary eras in the so-called East as well as the West ${ }^{49}$.

46 Adeline Rucquoi, "Gundisalvus ou Dominicus Gundisalvi”, Bulletin de Philosophie Médiévale, XLI, 1999, p. 85.

47 Dag Nikolaus Hasse, "The Social Conditions of the Arabic-(Hebrew-) Latin Translation Movements in Medieval Spain and in the Renaissance.", Wissen über Grenzen: Arabisches Wissen und lateinisches Mittelalter, 2006, p. 69.

48 See also two important references for the influence of Arabic works on the Italian Renaissance and Medici Family: Nancy G. Siraisi, Avicenna in Renaissance Italy: the Canon and Medical Teaching in Italian Universities after 1500, Vol. 789, Princeton University Press, 2014;

49 Catherine Wilson, "Modern Western Philosophy", History of Islamic Philosophy, Vol. 2/2, 1996.

Belleten, Nisan 2021, Cilt: 85/Sayı: 302; 29-51 
Averroes defended ${ }^{50}$ the works of Plato and Aristotle on political thought and democracy while developing it further in his doctrine of Unity of Truth. Ibn Rushd's original work on philosophy, Incoherence of the Incoherence (Taha'fut Al Taha'fut) includes his defence of Aristotle's philosophy. Averroes' philosophical thought based on his commentaries on Plato and Aristotle gave birth to the $13^{\text {th }}$ century European political thought so-called Averroism. According to Averroes, there is one truth only. The knowledge of truth through religion cannot be tested and nor does it require any training to be known. The other is the knowledge of truth through the philosophy that requires intellectual endeavour to reach the truth ${ }^{51}$.

These philosophies of Plato and Aristotle preserved by Averroes were reintroduced to $13^{\text {th }}$ century Europe after almost 800 years since the destruction of Plato and Aristotle academies in Athens and Alexandria by the Christian Church. The philosophical works of Averroes translated through the scholars at Padua University led to the development of the Padua Averroism. It is a different matter beyond the scope of this discussion that later Padua scholars who were introduced to the works of Aristotle attacked Averroes for his doctrine of Unity of Truth. Thomas Aquinas referred to Aristotle simply as the Philosopher and Averroes as the Commentator. Bishop Étienne Tempier in 1270 AD and 1277 AD $^{52}$ most notably led the Catholic Church's condemnations of Plato and Aristotle made available through Ibn Rushd's work.

Italian Renaissance scholars such as Pico Della Mirandola and Giordano Bruno chose to shun the Christian Canon and pursued the ancient Greek philosophies of Plato and Aristotle based on the works of Averroes. The fullest work of Averroes in Latin can be found in the $16^{\text {th }}$ century Juntine Edition ${ }^{53}$.

\section{The Medici's Influence on the European Renaissance}

The history of Europe from $200 \mathrm{AD}$ to $1360 \mathrm{AD}$ was intentionally left out. The reason is that the general narrative of European political history takes the position

50 Robert Irwin, Dangerous knowledge: Orientalism and its Discontents, Overlook, Woodstock, 2006, p. 102.

51 Majid Fakhry, Averroes: His Life, Work and Influence, Oneworld Publications, Oxford 2001, p. 20.

52 Carol Lea Clark, "Aristotle and Averroes: The Influences of Aristotle's Arabic Commentator upon Western European and Arabic Rhetoric.", The Review of Communication, Vol. 7/4, 2007, p. 370.

53 Juntine Edition is Averroes Latin works on Aristotle published in Venice 1562-1574. Charles Burnett, "Aristotle: The Giuntine Edition", In Encyclopedia of Renaissance Philosophy, edited by Marco Sgarbi, 1-3. Cham: Springer International Publishing, 2017, p. 3. 
of inert detente of political thought. The narrative proposes that the re-emergence of the Platonian and Aristotelian ancient Greek philosophy in $13^{\text {th }}$ century Europe is marked by the Italian statesman and political philosopher Machiavelli. This baffling gap of 1500 years is yet unexplained.

It seems that there was no room for any pagan philosophy of ancient Greeks, notably Plato and Aristotle during the 1500 years march of European political thought that led to its re-emergence during the Italian Renaissance. It is also not clear if the Christian Church during the time between the $6^{\text {th }}$ century AD and $13^{\text {th }}$ century AD was more concerned with the suppression of the political philosophies of ancient Greeks or the increasing influence of Islamic scholarship that has preserved the ancient Greek philosophies in Arabic ${ }^{54}$. Perhaps it was both. The Roman Christian Church found it essential to oppose the re-introduction of the ancient Greek philosophies that were available to the $13^{\text {th }}$ and $14^{\text {th }}$ century European scholars through the Arabic translations by Ibn Rushd. It is also clear from earlier references to the Latin translations of ancient Greek texts by the Arabic scholars that led to the re-introduction of ancient Greek philosophies and their political thought during the Italian Renaissance ${ }^{55}$. The Italian Renaissance would be an imperfect history without the Medici of Florence (1360-1642 AD). Their profound impact on Europe is marked by Giovanni De Bicci De Medici (1360-1429 AD) who made the Medici's the wealthiest family in Europe to Marie De Medici (1575-1642 AD), the Queen and Regent of France.

The most noted Medici ruler for the purposes of this study and who merits the most recognition for the Italian Renaissance that led to the European Renaissance is Lorenzo de' Medici (1449-1492 AD). He is an influential figure in the history of literature and art from all that is noteworthy for the Renaissance period of European history. His patronage of Renaissance artists such as Leonardo da Vinci (1452-1519) and Michelangelo Buonarroti (1475-1564), scientists such as Galileo Galilei and Nobility scholars such as Count Giovanni Pico Della Mirandola (14631494) (Pico) who were all Neo-Platonic.

Lorenzo's two sons, Giovanni De’ Medici (1475-1523) was his adopted son, and Giulio De' Medici (1478-1534) was his biological son, later became Pope Leo X and Pope Clement VII. Pope Clement VII commissioned Michelangelo Buonarroti to paint the altar of the Sistine Chapel. The Sistine Chapel itself was

54 James Aloysius Kritzeck, Peter the Venerable and Islam, Princeton University Press, 2015, p. 24.

55 C. Wilson, "Modern Western Philosophy", History of Islamic Philosophy, Vol. 2/2, 1996. 
built by the Medici family. The Medici family provided a safe haven for Galileo Galilei due to his persecution by the Christian Church for his scientific studies of the Celestial bodies that negated the views of the Christian faith.

Count Giovanni Pico renounced canon law and studied philosophy and learned Arabic and Hebrew at the University of Padua. Padua became the centre of Aristotelianism in Italy due to Averroes' philosophical translations from Arabic to Latin and Hebrew. Both Hebrew and Arabic were amongst the leading languages taught at Padua. It was Lorenzo's Royal patronage that allowed Count Pico and his teacher Marsilio Ficino to expand the ancient Greek philosophies during the Italian Renaissance. Ficino's Latin translation of Plato's work influenced Pico's later work on Aristotle, trying to reconcile the Christian faith with Aristotelian philosophies. Both Ficino and Pico ${ }^{56}$ relied on Ibn Rushd's commentaries on Plato and Aristotle, in which Ibn Rushd had removed the tension and reconciled the link between religion and philosophy. Ibn Rushd's work on reconciliation and allowance to rely on philosophy in the Islamic Law interpretations is eloquently documented in his book Fasal Al Maqal ${ }^{57}$ that provides Islamic jurists with the legal framework rely on philosophical investigations under the Islamic Legal doctrines. These works of Ibn Rushd translated into Latin and Hebrew guided the thoughts of Renaissance scholars such as Pico, Bruno, and Aquinas.

The rise of Orthodox Christian reformers and the constant intrigues within the Roman Christian Church led to the political instability leading to the fall and ultimate expulsion of the Medici family from Florence towards the end of the $15^{\text {th }}$ century. The conflict also led to the wholesale destruction of valuable art and literature from the Medici Library produced under the patronage of the Medici family. The death of Lorenzo in 1492 was proceeded by the French invasion of Florence in 1494, ending the golden era of the Italian Renaissance. It must be pointed out that the Roman Church was instrumental in the French invasion in 1494 that followed 400 years of the French occupation of the Italian peninsula. The end of the Medici family's rule in Florence shifted the European centre of Renaissance from Florence to Rome.

56 Yehuda Halper, "Elia del Medigo, Averroes and Averroism", Philosophy and the Fewish Tradition, Brill, 2012, p. 52.

57 G. F. Hourani Averroes, Kitab fasl al-maqal, 1959. 


\section{Euro-Arab Tradition in Transmitting Plato and Aristotle to Europe}

The study has already given a brief overview of the existing standard linear historical narrative about the history of political thought in Europe and the use of political canon and the contemporary western linear view of its history. The stagnation of European political thought from 22 BC till Machiavelli (1469-1532 $\mathrm{AD}$ ) is considered without a blink of an eye. Cicero, Roman Stoics, and even Aquinas are considered to be outside the scope of the standard narrative.

The Euro-Arab tradition ${ }^{58}$ that covered the extended ancestry of Plato and Aristotle's philosophical thoughts across regions and empires is, in reality, the result of a rich inter-cultural, multi-ethnic Greek text that reflects the Platonic and Aristotelian thought through the lens of multiple religious, ethnic, and cultural views. It is not just western; it is the scholarly heritage of many centuries of intellectual dialogue between so-called European and Arab scholars.

The role of Islamic scholars such as Ibn Rushd has been minimised as mere scribes who for reasons unknown took upon themselves to preserve the Greek text in Arabic while the Christian Church was busy burning the libraries of Alexandria and burning alive Platonic and Aristotelian scholars who fled to the Islamic Learning Centres of Baghdad and Cordoba. This inert preservation and further transmission of the Greek texts in Arabic translations does not rhyme with the western view of Islam as being back-ward, rigid and based on ideologies that are divine revelations and not logical.

These are the views that unfortunately still underline the understating of Islam according to the $19^{\text {th }}$ century oriental and colonial imperialism and define Muslims as the Oriental man. The contemporary so-called Western liberal political thought is often linked to the political philosophies of Plato and Aristotle as being the foundation of the contemporary western identity. Western identity is still based on the other as a reference point. The 'other' for the frame of reference refers to Muslims, non-Christian Africans, and the indigenous people of the North and South America ${ }^{59}$.

It is not surprising that the presence of Islam in western thought still represents a threat to western civilisation and also serves as a point of reference for the western identity as the Muslim especially as the 'other'. Ibn Rushd is a European from

59 K. H. Bullock, "Re-Telling the History of Political Thought", American Fournal of Islamic Social Sciences, Vol. 19/1, 2002, p. 30. 
Spain, and Al Farabi (870-950 AD) is a Turk. Machiavelli himself discussed the Turks in his discourse, The Prince $e^{60}$. Nevertheless, both have been cast outside the European history of political thought.

\section{Conclusion}

The contributions of the Medici family are often minimised for their role as the wealthiest family of Europe at the peak of their rule in Florence and the Medici Bank only. What needs further research is the patronage that the Medici family provided to scholars and artists whose work reflects the deep intellectual links with the Islamic world at the time and the political transformation of Europe.

The role of the Medici family in the Italian Renaissance is not only significant for understanding the evolution of European political thought but also it is the irrefutable proof of the crucial role that Islamic scholars like Ibn Rushd played in preserving the philosophies of ancient Greeks like Plato and Aristotle. The Medici family recognised the crucial role of providing patronage for scholarship and art. They did not face the biases of the time against cultures foreign to Europe through their financial politics, and the Medici' had a much broader view of world politics what existed at the time. The proof of their emancipation is reflected in the presence of pseudo-Arabic scripts found in the famous artworks of the time ${ }^{61}$. The present altered narrative of the history of political thought and western philosophies is deficient as to the 800 years gap between philosophical thoughts of Aristotle and Machiavelli. This narrow and linear narration of the history of the political thought based on the ancient Greek works of Plato and Aristotle deprives the present and future generations of scholars from the rich alternative corpus politic left by the Islamic scholars like Ibn Rushd in Arabic literature. There is a need for an unbiased and comprehensive joint study of the Medici rulers that can reflect the parallel critical analysis of the scholarship and art during their time. The Medici Bank was not just a financial institution formed by a dynasty of wealthy rulers, and it was an institution understanding human nature in body of society through providing patronage for scholarship and providing patronage for scholarship and art.

60 Nathan Tarcov, “Machiavelli’s Critique of Religion”, Social Research: An International Quarterly, Vol. $81 / 1,2014$.

61 Stanley Ferber, Islam and the Medieval West, Vol. 1, Suny Press, 1979. 


\section{BIBLIOGRAPHY}

Averroes, G. F. Hourani, Kitab fasl al-maqal, 1959.

Ball, Terence, Reappraising Political Theory: Revisionist Studies in The History of Political Thought, Vol. 2, Oxford University Press, 1995.

Baron, Hans, "Machiavelli: the republican citizen and the author of' The Prince", The English Historical Reviere, Vol. 76/299, 1961, pp. 217-259.

Bruscoli, Francesco Guidi, Papal Banking in Renaissance Rome: Benvenuto Olivieri and Paul III, 1534-1549, Routledge, (2017).

Bullock, Katherinig H., "Re-Telling the History of Political Thought", American Journal of Islamic Social Sciences, Vol. 19/1, 2002, pp. 29-50.

Burnett, Charles, "Aristotle: The Giuntine Edition". In Encyclopedia of Renaissance Philosophy, edited by Marco Sgarbi, 1-3. Cham: Springer International Publishing, 2017.

Cashill, Jack, Popes and Bankers: A Cultural History of Credit and Debt, from Aristotle to $A I G$, Thomas Nelson, 2010.

Catalouge of The Medici Archives Consisting of Rare Autograph Letters Records and Documents 1084-1770 Including One Hundred And SixtySix Holograph Letters Of Lorenzo The Magnificent The Property of The Marquis Cosimo De' Medici and The Marquis Averardo De' Medici, https:// archive.org/search.php?query=medici\&page=2, (1918), p. 24 .

Gurran, Charles E. - Richard, A. McGormick, The Magisterium and Morality, 1982.

Davis, Leo Donald, The first seven ecumenical councils (325-787): their history and theology, Vol. 21. Liturgical Press, 1990.

De Roover, Raymond, "New Perspectives on The History of Accounting", The Accounting Reviere, Vol. 30/3, 1955, pp. 405-420.

De Roover, Raymond, The Rise and Decline of the Medici Bank: 1397-1494, Vol. 21, Beard Books, 1999.

Della Famiglia De Medici in Firenze Appresso Bartolommeo Sermartelli e Fratelli MDCX, https://archive.org/details/dellafamigliadem00stro/page/n3

Dietz, Mary G., "Trapping the Prince: Machiavelli and the Politics of Deception", American Political Science Reviere, Vol. 80/3, 1986, pp. 777-799. 
Ekelund, Robert B.- Hébert, Robert F. - Tollison, Robert D., "An Economic Model of The Medieval Church: Usury As A Form of Rent Seeking", Fournal of Law, Economics, \& Organization, Vol. 5/2, 1989, pp. 307-331.

Fakhry, Majid, Averroes: His Life. Work and Influence, Oneworld Publications, Oxford 2001.

Ferber, Stanley, Islam and the Medieval West, Vol. 11, Suny Press, 1979.

Fisher, D. Havelock, "The Medici Account-Books", The American Historical Review, Vol. 33/4, 1928, pp. 829-831.

Fleischacker, Samuel, The ethics of culture, Cornell University Press, (1994).

Ghazanfar, S. M., "History of Economic Thought: The Schumpeterian "Great Gap", the "lost" Araba-Islamic Legacy and the Literature Gap", Medieval Islamic Economic Thought, Routledge, 2004, pp. 88-103.

Gilbert, Allan H., Machiavelli's Prince and its Forerunners, 1938.

Goff, Jacques Le, The Usurer and Purgatory, in The Dawn of Modern Banking, 1979, pp. 25-53.

Goldthwaite, Richard A., "The Medici Bank and the world of Florentine Capitalism", Past \& Present, No. 114, 1987, pp. 3-31.

Grabar, Oleg - Cynthia Robinson, (eds.), Islamic Art and Literature, Markus Wiener Publishers, 2001.

Halper, Yehuda, "Elia del Medigo, Averroes and Averroism", Philosophy and the Fereish Tradition, Brill, 2012, pp. 51-62.

Hasse, Dag Nikolaus, "The Social Conditions of the Arabic-(Hebrew-) Latin Translation Movements in Medieval Spain and in the Renaissance", Wissen über Grenzen: Arabisches Wissen und lateinisches Mittelalter, 2006, pp. 68-88.

Heer, Friedrich, The Medieval World: Europe, 1100-1350, Welcome Rain, (1998).

Hodgson, Marshall G. S., The Venture of Islam, Volume 1: The Classical Age of Islam, Vol. 1, University of Chicago Press, 2009.

Hodgson, Marshall G. S., Rethinking world history: essays on Europe, Islam and World History, Cambridge University Press, 1993.

Irwin, Jones, Averroes' Reason: A Medieval Tale of Christianity and Islam, 2002.

Irwin, Robert, Dangerous knowledge: Orientalism and its Discontents, Woodstock, 2006. 
Kritzeck, James Aloysius, Peter the Venerable and Islam, Princeton University Press, 2015.

Lea Clark, Carol, "Aristotle and Averroes: The Influences of Aristotle's Arabic Commentator upon Western European and Arabic Rhetoric", The Review of Communication, Vol. $7 / 4$ 2007, pp. 369-387.

Machiavelli, Niccolò, The Prince, (Translation by George Bull), Penguin, London 1961.

Mack, Rosamond E., (Book Review), "Bazaar to Piazza, Islamic Trade and Italian art, 1300-1600”, Middle East Fournal, Vol. 56/4, 2002, pp. 721-723.

Marshall, P. J., Proceedings of the British Academy Volume 125, 2003 Lectures, Vol. 125, Proceedings of the British Academy, 2005.

Menocal, Maria Rosa, The Arabic Role in Medieval Literary History: a Forgotten Heritage, University of Pennsylvania Press, 2004.

Nasr, Seyyed Hossein - Oliver Leaman, History of Islamic Philosophy, Routledge, 2013.

Parks, Tim, Medici Money: Banking, Metaphysics, and Art in Fifteenth-Century Florence, WW Norton \& Company, 2005.

Partner, Peter, "Papal Financial Policy in the Renaissance and CounterReformation”, Past \& Present, Vol. 88/1, 1980, pp. 17-62.

Peters, F. E., (Book Review), Aron Rodrigue: "Jews and Muslims: Images of Sephardi and Eastern Jewries in Modern Times", International Fournal of Middle East Studies, Vol. 37/2, 2005, pp. 295-296.

Rahe, Paul A., Machiavelli's Liberal Republican Legacy,Cambridge University Press, 2005.

Reinert, Erik - A. Daastol, The other Canon: The History of Renaissance Economics, Cheltenham, Edward Elgar, 2004.

Rucquoi, Adeline, "Gundisalvus ou Dominicus Gundisalvi", Bulletin de Philosophie Médiévale, XLI, 1999, pp. 85-106.

Siraisi, Nancy G., Avicenna in Renaissance Italy: the Canon and Medical Teaching in Italian Universities after 1500, Vol. 789, Princeton University Press, 2014.

Shayegan, Yegane, "The Transmission of Greek Philosophy to the Islamic World", History of Islamic Philosophy, Vol. 1, 1996, pp. 89-104. 
Strathern, Paul, The Medici: Godfathers of the Renaissance, Random House, 2018.

Stuurman, Siep, "The Canon of The History of Political Thought: Its Critique and A Proposed Alternative", History and Theory, Vol. 39/2, 2000, pp. 147166.

Tarcov, Nathan, "Machiavelli’s Critique of Religion", Social Research: An International Quarterly, Vol. 81/1, 2014, pp. 193-216.

Turner, Bryan S., Max Weber-Critical Responses, Routledge, 1999.

Wilson, Catherine, "Modern Western Philosophy", History of Islamic Philosophy, Vol. 2/2, 1996, pp. 1021-1023.

Young, George Frederick, The Medici, Vol. 1, EP Dutton, 1917. 
